\title{
PRENATAL DIAGNOSIS IN MACEDONIAN DUCHENNE MUSCULAR DYSTROPHY FAMILIES
}

\author{
Kocheva $\mathrm{SA}^{1,2}$, Trivodalieva $\mathrm{S}^{1}$, Plaseska-Karanfilska $\mathrm{D}^{1}$, \\ Vlaski-Jekic $\mathrm{S}^{3}$, Kuturec $\mathrm{M}^{2}$, Efremov GD ${ }^{1, *}$
}

\begin{abstract}
*Corresponding Author: Professor Dr. Georgi D. Efremov, Macedonian Academy of Sciences and Arts, Research Center for Genetic Engineering and Biotechnology, Aven Krste Misirkov 2, POB 428, 1000 Skopje, Republic of Macedonia; Tel.: +3892-120253; Fax: +3892-115434; E-mail: gde@manu.edu.mk
\end{abstract}

\begin{abstract}
Duchenne muscular dystrophy (DMD) is an Xlinked recessive disorder caused by mutations in the dystrophin gene at Xp21.2. Mutations include gross deletions $(60 \%)$, duplications $(10 \%)$, and point mutations (30\%). Duchenne muscular dystrophy is a serious and disabling disease. Progressive muscle wasting, which leads to severe disability and early death, make DMD highly distressing disorders to both patient and family. Since no effective treatment is as yet available, prenatal diagnosis is important for prevention of the disease. In this paper, we present our results from prenatal diagnoses in Macedonian DMD families. For prenatal diagnosis of 15 pregnancies at risk of having a DMD child, we used multiplex polymerase chain reaction (mPCR), multiplex ligation-dependent probe amplification analysis (MLPA) and DNA linkage analysis, using highly polymorphic intragenic short tandem repeat [STR(CA) n] markers. DNA material was extracted from chorionic villus and amniotic fluid samples. Eight of the fetuses were male, three of whom had dele-
\end{abstract}

1 Macedonian Academy of Sciences and Arts, Research Center for Genetic Engineering and Biotechnology, 1000 Skopje, Republic of Macedonia

2 Pediatric Clinic, Faculty of Medicine, 1000 Skopje, Republic of Macedonia

3 Neurology Clinic, Faculty of Medicine, 1000 Skopje, Republic of Macedonia tions in the dystrophin gene and five were normal. Two of the female fetuses were carriers of deletions in the dystrophin gene.

Key words: Duchenne muscular dystrophy (DMD); Multiplex polymerase chain reaction (mPCR); Multiplex ligation-dependent probe amplification (MLPA); Short tandem repeat (STR).

\section{INTRODUCTION}

Duchenne muscular dystrophy (DMD) is one of the most commonly inherited neuromuscular diseases, affecting one in 3,500 live-born males. It is an X-linked recessive disorder caused by mutations in the DMD gene located at Xp21.2 [1]. This is the largest identified gene in the human genome, spanning $2.4 \mathrm{Mb}$ and contains 79 exons. It has a high mutation rate, approximately one-third of cases resulting from spontaneous mutations. Its transcript is 14 $\mathrm{kb}$ long and is expressed in skeletal muscle and the brain $[2,3]$. The dystrophin protein gene product is involved in linkage between the extracellular matrix and the cellular cytoskeleton [4-6]. Partial deletions and duplications of the dystrophin gene account for $60-70 \%$ of all DMD cases, while the rest have point mutations [7-9]. The affected subjects die from respiratory failure in their early twenties. Because of limitations of therapy at the present time, prenatal diagnosis is important in detection and prevention of the disease. Here, we present results of prenatal diagnoses of DMD in Macedonian families. 


\section{MATERIALS AND METHOD}

Fifteen families at risk of having a child with DMD were referred to the Research Center for Genetic Engineering and Biotechnology at Skopje in the Republic of Macedonia for genetic counseling and prenatal diagnosis. Nine of the families were of Macedonian ethnic origin, while six were of Albanian origin living in Macedonia. Probands in 11 families were previously found to have deletions of different exons of the dystrophin gene, one had a gene duplication and in three the mutation was unknown.

DNA was extracted from chorionic villus samples (CVS) in seven pregnancies (in the first trimester of pregnancy), and amnionic fluid in eight pregnancies (in the second trimester of pregnancy). DNA was extracted from CVS or amniocytes following a standard phenol/chloroform extraction procedure [10]. Prenatal diagnosis was based on a combination of the following: 1) DNA analysis of the dystrophin gene by direct detection of deletions by multiplex polymerase chain reaction (mPCR) [11-13]; 2) Multiplex ligation-dependent probe analysis (MPLA) for detection of deletions and duplications [14] and 3) DNA linkage analysis, using eight highly polymorphic intragenic short tandem repeats [STR-(CA)n] for the detection of abnormal $\mathrm{X}$ chromosomes in the families with unknown mutation $[15,16]$. To exclude maternal cell contamination, DNA analysis was performed on CVS and on amniocytes by quantitative fluorescent (QF)-PCR analysis of 15 STR markers on chromosomes 13, 18, 21 and $\mathrm{X}$, as well as the amelogenine gene for sex determination.

1) Multiplex Polymerase Chain Reaction. More than $98 \%$ of the deletions of the dystrophin gene are readily detectable using an MPCR approach, based on an exon by exon analysis strategy within two hot-spot regions (exons 2-22 and 44-53). Multiplex PCR was performed in three assays (Set A: exons 4, 8, 12, 17, 19, 44, 45, 48 and 51; Set B: exons Pm, 3, 6, 13, 43, 47, 50, 52 and 60; Set C: exons 16, 32, 41, 42 and 49) allowing the amplification of 23 exons [11-13]. Fetal DNA was amplified using specific oligonucleotide primers for 23 exons of the dystrophin gene. Multiplex PCR was carried out in a final volume of $50 \mu \mathrm{l}$ containing $100 \mathrm{ng}$ of genomic DNA, $30 \mathrm{pmol}$ of each primer, $200 \mu \mathrm{M}$ each dNTP, standard PCR buffer, $1.5 \mathrm{mM} \mathrm{MgCl}$ and $2 \mathrm{U}$ Taq DNA polymerase (AmpliTaq Gold, Applied Biosystems, Branchburg, NJ, USA). Samples were subjected to 30 cycles of amplification, each consisting of $1 \mathrm{~min}$. at $94^{\circ} \mathrm{C}, 1 \mathrm{~min}$. at $53-55^{\circ} \mathrm{C}$ and $4 \mathrm{~min}$. at $72^{\circ} \mathrm{C}$, and a final extension of $72^{\circ} \mathrm{C}$ for $10 \mathrm{~min}$. The PCR products were electrophoresed on $3 \%$ agarose gel in a TBE buffer and visualized under UV light after ethidium bromide staining. Deletions were easy to visualize by PCR-based procedures in males, because of their hemizygosity for this gene. The analysis is based on discrimination between the presence and absence of a PCR product. The duplications of exons, however cannot be visualized by a PCR-based assay.

2) Multiplex Ligation-Dependent Probe Amplification Analysis (MLPA). This assay for the DMD gene was performed on nine samples and required two different reactions due to the large number of exons [14]. One reaction contained probe mix PO34 that covered exons 1-20, 21-30, 41-50 and 61-70. The second reaction contained probe mix PO35 and covered exons 11-22, 31$40,51-60$, and 71-79. The assay conditions were essentially according to the manufacturer's recommendations (MRS Holland, Amsterdam, The Netherlands). The PCR products were analyzed by capillary electrophoresis on an ABI PRISM ${ }^{\mathrm{TM}} 310$ Genetic Analyzer (Applied Biyosystems).

3. DNA Linkage Analysis. For DNA polymorphism within or flanking the dystrophin gene $[15,16]$, the PCR was carried out in a final volume of $50 \mu \mathrm{L}$ containing $100 \mathrm{ng}$ of genomic DNA, 30 pmols of each primer, $200 \mu \mathrm{M}$ each dNTP, standard PCR buffer, $1.5 \mathrm{mM} \mathrm{MgCl}_{2}$ and $2 \mathrm{U}$ Taq DNA polymerase (Ampli Taq Gold, Applied Biosystems). Samples were subjected to 35 cycles of amplification consisting each one of $1 \mathrm{~min}$. at $94^{\circ} \mathrm{C}$, $1 \mathrm{~min}$. at $55-60^{\circ} \mathrm{C}$ and $1 \mathrm{~min} .30 \mathrm{sec}$. at $72^{\circ} \mathrm{C}$ and a final extension at $72^{\circ} \mathrm{C}$ for $10 \mathrm{~min}$. Aliquots of PCR products were mixed in a half volume of formamide dye solution ( $98 \%$ formamide, 10 mMEDTA, 0.1 bromphenol blue and $0.1 \%$ xylen cyanol), heated to $94^{\circ} \mathrm{C}$ for $3 \mathrm{~min}$., and electrophoresed on a $6 \%$ denaturing polyacrylamide sequencing gel. Following electrophoresis the samples were transferred onto the membrane and analyzed after hybridization with a $(\mathrm{CA}) \mathrm{n}$ repeat probe. 


\section{RESULTS AND DISCUSSION}

We have previously studied the molecular basis of DMD/BMD in 94 Macedonian patients and have characterized most of our patients at the molecular level [17]. Mutations of the dystrophin gene were found in $76.5 \%$ (72/94), $72.3 \%$ being deletions (68/94) and 4.2\% (4/94) being duplications. Genetic counseling has been given to all DMD families. Appropriate information about the disease and its genetic aspects were provided and the possibility and limits of genetic testing were discussed. Prenatal diagnosis (on request and after genetic counseling) was performed in 15 families at risk of having a DMD child. Representative results from MPCR, MLPA and STR analysis are shown on Figures 1, 2 and 3. Eight of the fetuses were males. Three were affected with deletions in the dystrophin gene and five were normal. The pregnancies were terminated for affected fetuses. Two of the seven female fetuses were carriers for deletions in the dystrophin gene.

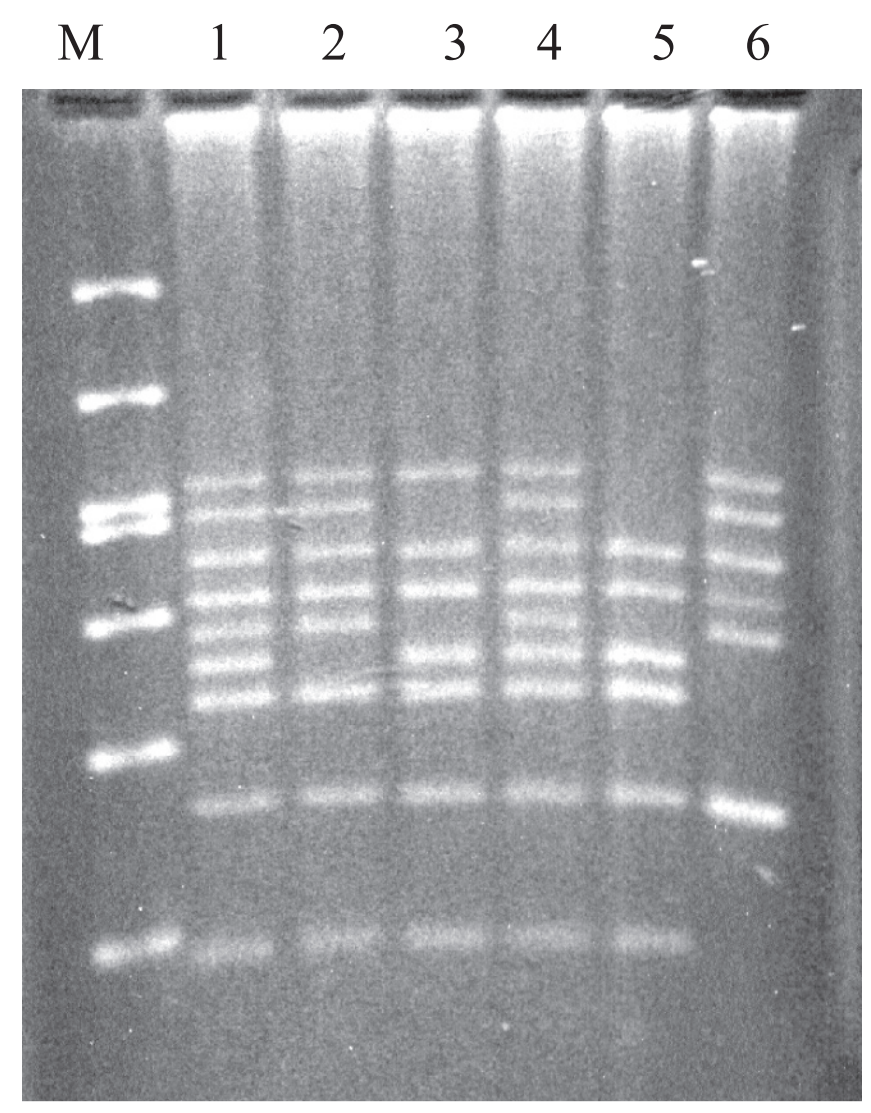

Figure 1. Detection of the deletions by mPCR analysis. Set A (exon: 45, 48, 19, 17, 51, 8, 12, 44 and 4). Lanes 1 and 4: control sample, lanes 2, 5 and 6: patients with different deletions in the dystrophin gene; lane 3: fetus DNA with a deletion of exons 48 and 51. 


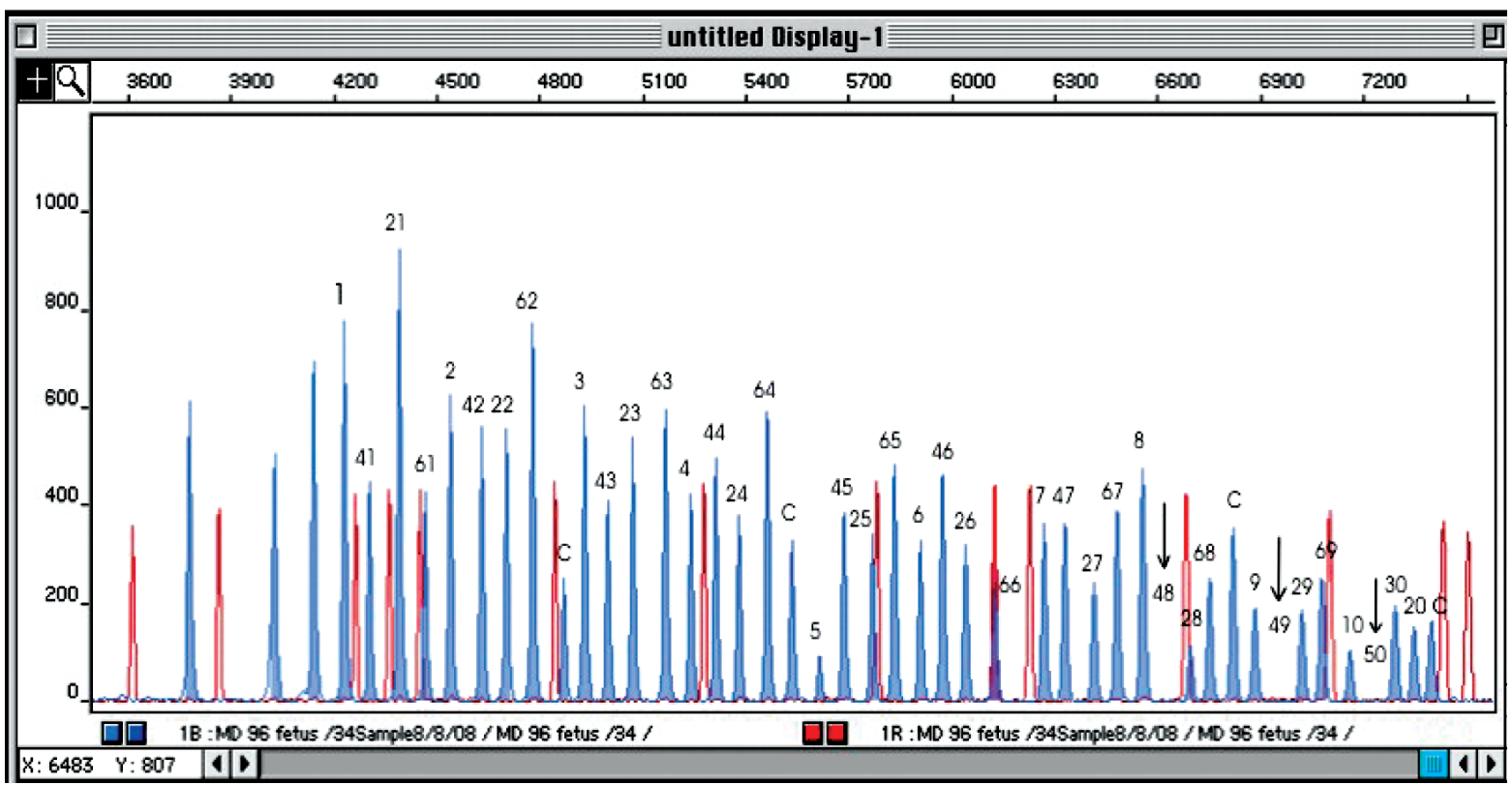

Figure 2. Multiplex ligation-dependent probe amplification analysis. The electropherogram shows a deletion of exons 48-50 of the DMD gene in an affected fetus. Number correspond to exon number; C: synthetic control probe.
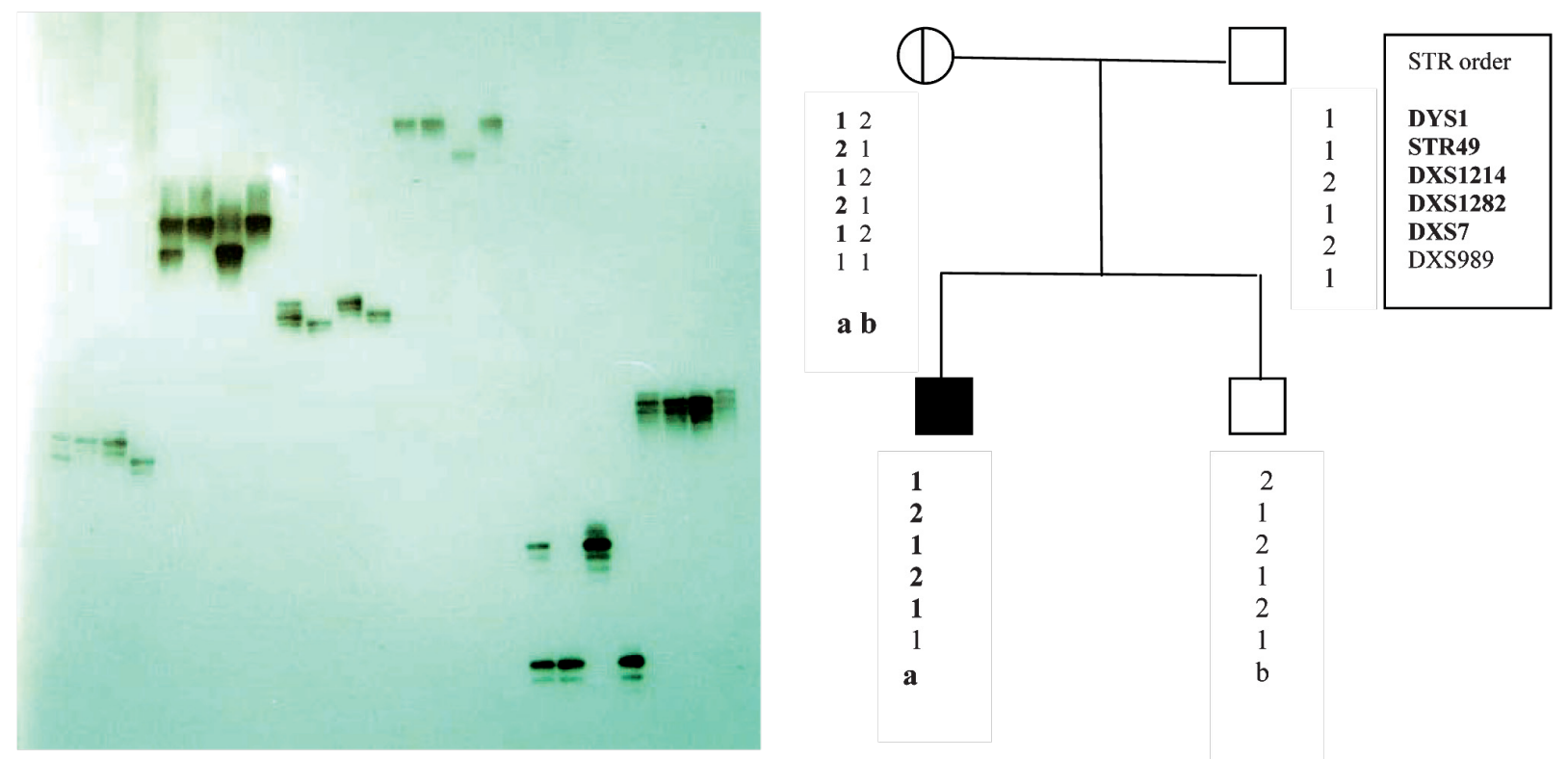

Figure 3. Haplotype analysis in one DMD family. A) Autoradiograph showing alleles at six STR-(CA) $n$ repeats in the dystrophin gene for members of a DMD family. Haplotypes can be constructed using polymorphic markers across the gene to identify the haplotype which is tracking with the mutant dystrophin gene. B) Pedigree and allele assignments in this DMD family. In the example shown here, the mother is heterozygous for five STR markers (DYS1, STR 49, DXS, DXS 1282 and DXS7), which were detected in the proband. Haplotype "a" in the proband indicates a high risk for DMD. The fetus (f) inherited the normal X chromosome (haplotype b). 


\section{ACKNOWLEDGMENTS}

This study was supported by grants No. 4008662/98 from the Ministry of Science of the Republic of Macedonia and No. 11-513/1 from the science funds of the Macedonian Academy of Sciences and Arts, Skopje, Republic of Macedonia (both to GDE).

\section{REFERENCES}

1. Worton RG, Thompson MW. Genetics of Duchenne muscular dystrophy. Annu Rev Genet 1988; 22: 601-629.

2. Hoffman EP, Brown RH Jr, Kunkel 1M. Dystrophin: the protein product of the Duchenne muscular dystrophy locus. Cell 1987; 51(6): 919-928.

3. Den Dunnen JT, Grootscholten PM, Dauwerse JG, Walker AP. Reconstruction of the $2.4 \mathrm{Mb}$ human DMD gene by homologous YAC recombination. Hum Mol Genet 1992; 1(1): 19-28.

4. Yoshida M, Ozawa E. Glycoprotein complex anchoring dystrophin to sarcolemma. J Biochem 1990; 108(5): 748-752.

5. Ervasti JM, Campbell KP. Membrane organization of the dystrophin-glycoprotein complex. Cell 1991; 66(6): 1121-1131.

6. Ervasti JM, Campbell KP. A role for the dystrophin-glycoprotein complex as a transmembrane linker between laminin and actin. J Cell Biol 1993; 122(4): 809-823.

7. Koenig M, Hoffman EP, Bertelson CJ, Monaco AP, Fenner C, Kunkel LM. Complete cloning of the Duchenne muscular dystrophy (DMD) cDNA and preliminary genetic organization of the DMD gene in normal and affected individuals. Cell 1987; 50(3): 509-517.

8. Den Dunnen JT, Grootscholten PM, Bakker E, Blonden LAJ, Ginjaar HB, Wapenaar MC, Van Paassen HMB, Van Broeckhoven C, Pearson PL, Van Ommen GJB. Topography of the Duchenne muscular dystrophy (DMD) gene FIGE and cDNA analysis of 194 cases reveals 115 deletions and 13 duplications. Am J Hum Genet 1989; 45(6): 835-837.
9. Roberts RG, Bobrow M, Bently DR. Point mutations in the dystrophin gene. Proc Natl Acad Sci USA. 1992; 89(6): 2331-2335.

10. Efremov GD, Dimovski AJ, Plaseska-Karanfilska D, Simjanovsa L, Sukarova E, Koceva S, Popovski Z. Laboratory Manual (2nd ed). ICGEB Affiliated Center "Nucleic acid based methods in human and veterinary medicine", Macedonian Academy of Sciences and Arts, Skopje, Republic of Macedonia 1998.

11. Chamberlain JS, Gibbs RA, Ranier JE, Nga Nguyen PN Caskey CT. Deletion screening of the Duchenne muscular dystrophy locus via multiplex DNA amplification. Nucleic Acids Res 1988; 16(23): 11141-11156.

12. Beggs AH, Koening M, Boyce FM, Kunkel LM. Detection of 98-percent DMD/BMD gene deletion by polymerase chain reaction. Hum Genet 1990; 86(1): 45-48.

13. Abbs SJ, Yau SC, Mathew CG Bobrow M. A convenient multiplex PCR system for the detection of dystrophin gene deletions: a comparative analysis with cDNA hybridization shows mistyping by both methods. J Med Genet 1991; 28(5): 304311.

14. Schouten JP, McElgunn CJ, Waaijer R, Zwijnenburg D, Diepvens F, Pals G. Relative quantification of 40 nucleic acid sequences by multiplex ligation-dependent probe amplification. Nucleic Acids Res 2002; 30: e57.

15. Beggs AH, Kunkel LM. A polymorphic CACA repeat in the 3' untranslated region of dystrophin. Nucleic Acid Res 1990; 18(7): 1931.

16. Feener CA, Boyce FM, Kunkel LM. Rapid detection of CA polymorphisms in cloned DNA: application to the 5 ' region of the dystrophin gene. Am J Hum Genet 1991; 48(3): 621-627.

17. Kocheva AS, Trivodalieva S, Vlaski-Jekic S, Kuturec M, Efremov DG. Identification of deletions and duplications of the DMD gene in Macedonian patients using Multiplex Ligation-dependent Probe Amplification (MLPA). Proceedings of the European Human Genetics Conference, Nice, France, June 2007. Eur J Hum Genet 15(Suppl 1): 191. 